
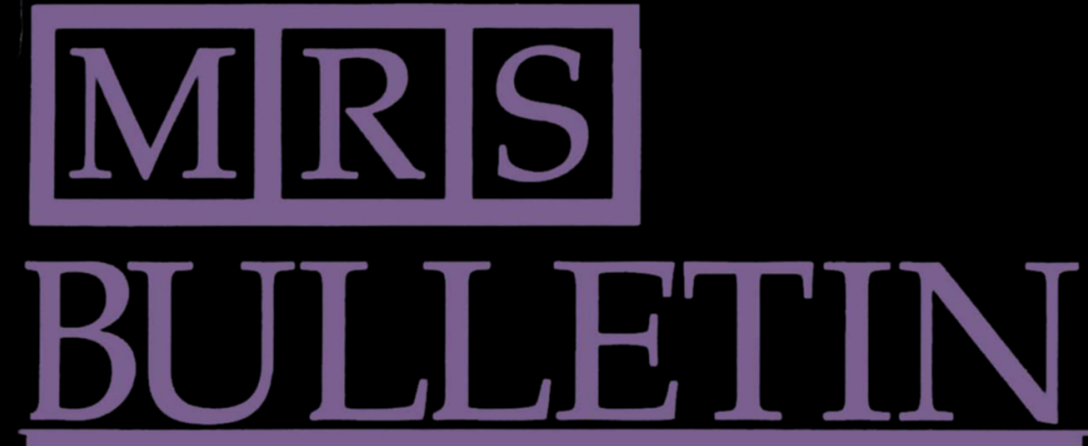

Serving the International Materials Research Community

A Publication of the Materials Research Society

August 1994, Volume XIX, No. 8

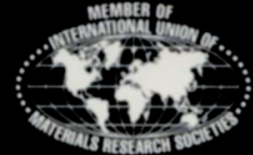

\title{
Copper Metallization
} in Industry

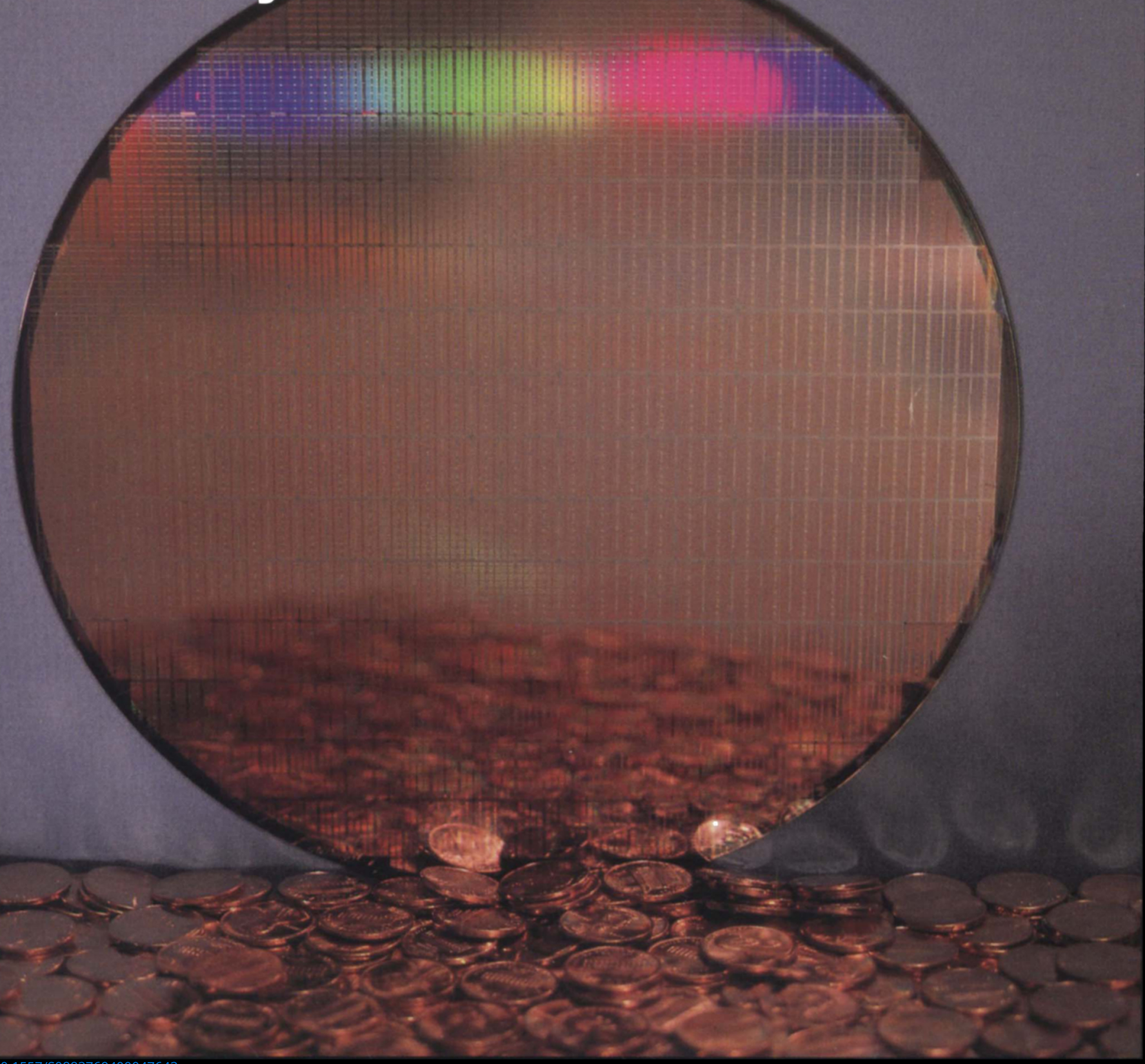




\section{HAVE YOU HEARD THE RUMOUR??}

...that High Voltage Engineering is currently developing a 3.5MV/TV -high current- tandem accelerator? Well... they are not, because HVEE has already finished the 3.5MV Tandetron and it performs extremely well!

In addition to higher terminal voltages, the HVEE Tandetron accelerators are now available with a novel, patented $90^{\circ}$ dual ion source -high currentinjector system and full computer control for unattended start-up and operation.

The new HVEE Tandetron accelerator systems can be installed in a single room laboratory without the need of a $\mathrm{HV}$ protection cage or additional X-ray shielding.

Circle no. 1 reader service card for product literature.
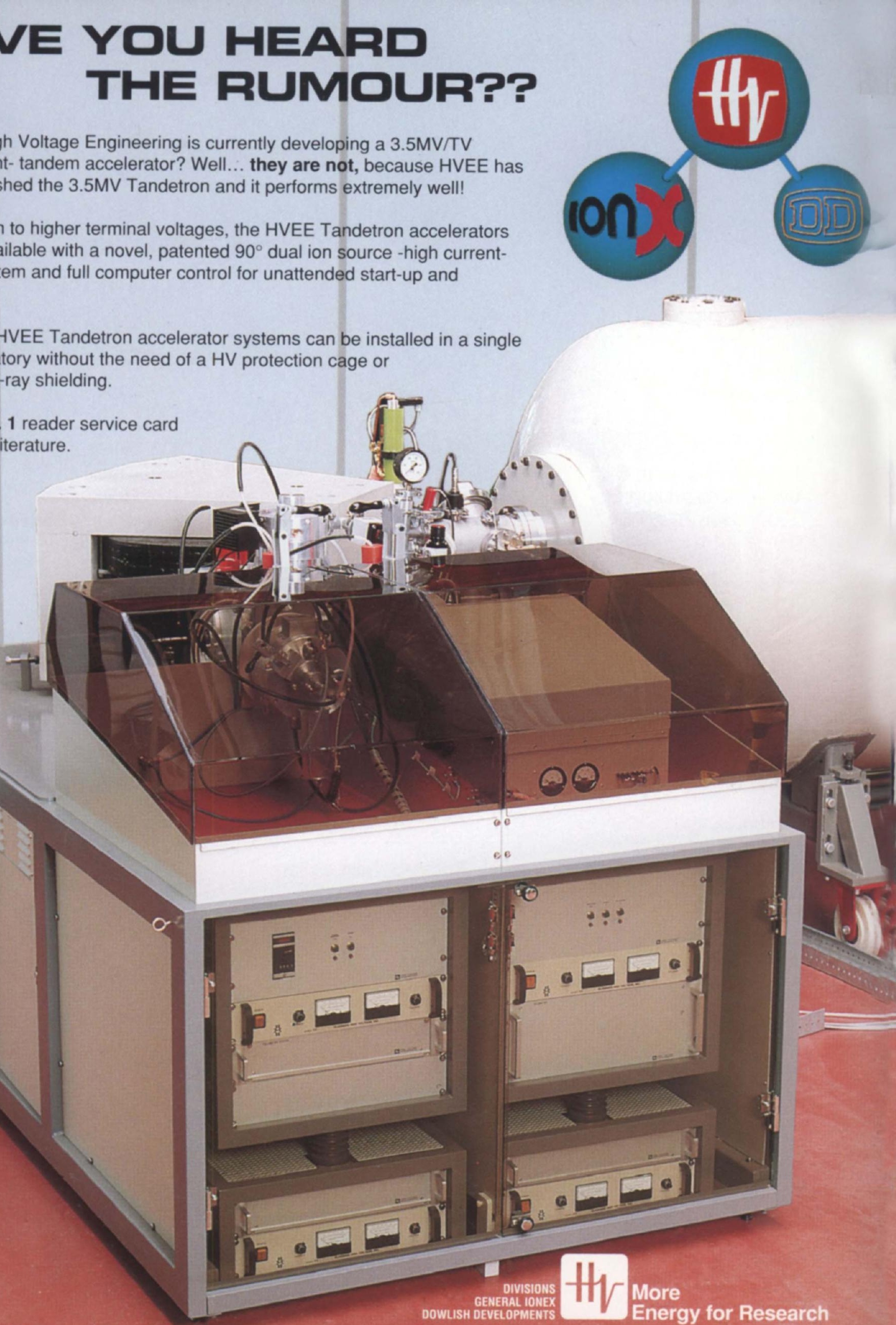
A Publication of the Materials Research Society

Volume XIX, Number 8 ISSN: 0883-7694 CODEN: MRSBEA

\section{COPPER METALLIZATION IN INDUSTRY}

15 Copper-Based Metallization in ULSI Structures

J. Li, T.E. Seidel, and J.W. Mayer, Guest Editors

23 Materials Issues in Copper Interconnections

J.M.E. Harper, E.G. Colgan,

C-K. Hu, J.P. Hummel,

L.P. Buchwalter, and C.E. Uzoh

30 Barriers Against Copper Diffusion into Silicon and Drift Though Silicon Dioxide S-Q. Wang

41 Chemical Vapor Deposition of Copper for IC Metallization: Precursor Chemistry and Molecular Structure P. Doppelt and T.H. Baum

49 Chemical Vapor Deposition of Copper for Advanced On-Chip Interconnects

A.V. Gelatos, A. Jain, R. Marsh, and C.J. Mogab

55 Electroless Copper Deposition on Metals and Metal Silicides Cecilia Y. Mak

63 Planarized Copper Multilevel Interconnections for ULSI Applications

N. Misawa, T. Ohba, and H. Yagi

68 Copper Metallization Technology for Deep Submicron ULSIs Y. Arita, N. Awaya, K. Ohno, and M. Sato

75 European Copper Interconnection Project J. Torres
INIERNATIONAL UNION OF MATERIALS RESEARCH SOCIETIES

76 C-MRS and E-MRS to Hold Symposium on Electronic and Optoelectronic Materials

\section{MRS NEWS}

77 Courses About Internet and Federal Materials Research Programs Debut at 1994 MRS Fall Meeting

77 Nominations Being Accepted for MRS Outstanding Young Investigator Award

78 Call for Papers - 1995 MRS Spring Meeting

\section{DEPARTMENTS}

4 Research/Researchers

10 From Washington

12 Resources

13 Editor's Choice

54 Advertisers in This Issue

81 Upcoming Conferences

83 Education Exchange

85 Historical Note

86 Library

87 Classified

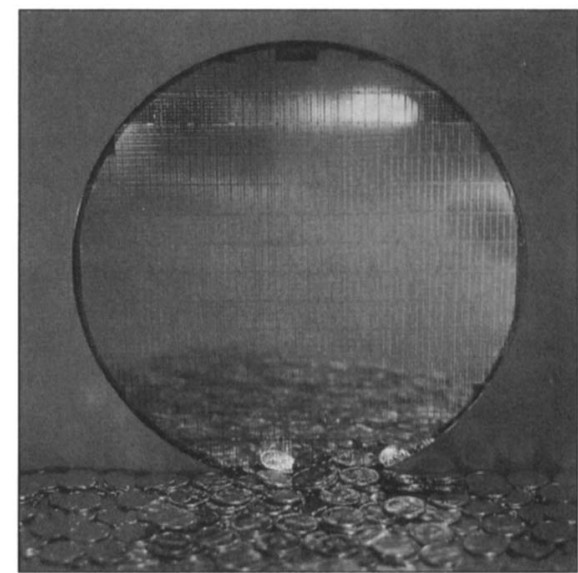

ON THE COVER: A $200 \mathrm{~mm}$ (8 inch) diameter silicon wafer with copper interconnections. The copper interconnection structure was developed and fabricated by members of IBM's Research Division and Microelectronics Division. The photograph was taken by D.C. Edelstein and E.G. Colgan. For more information about this topic, see "Materials Issues in Copper interconnections" by J.M.E. Harper and colleagues on p. 23. 


\section{About the Materials Research Society}

The Materials Research Society (MRS), a nonprofit scientific association founded in 1973, promotes interdisciplinary goal-oriented basic research on materials of technological importance. Membership in the Society includes nearly 11,600 scientists, engineers, and research managers from industrial, government, and university research laboratories in the United States and nearly 50 countries.

TheSociety's interdisciplinary approach differs from that of single-discipline professional societies because it promotes information exchange across the many technical fields touching materials development. MRS sponsors two major international annual meetings encompassing approximately 50 topical symposia, and also sponsors numerous single-topic scientific meetings. The Society recognizes professional and technical excellence, conducts short courses, and fosters technical interaction in local geographic regions through Sections and University Chapters.

MRS participates in the international arena of materials research through the International Union of Materials Research Societies (IUMRS). MRS is an affiliate of the American Institute of Physics.

MRS publishes symposium proceedings, MRS Bulletin, Journal of Materials Research, and other publications related to current research activities.

MRS Bulletin (ISSN. 0883-7694) is published 12 times a year by the Materials Research Society, $9800 \mathrm{McKnight}$ Road, Pittsburgh, PA 15237. Application to mail at second class rates has been approved at Pittsburgh, PA and at additional mailing offices. POSTMASTER: Send address changes to MRS Bulletin in care of the Materials Research Society, at the address listed; phone (412) 367-3003; Fax (412) 367-4373. Printed in the U.S.A.

Additional copies of articles in the MRS Bulletin may be made at $\$ 2.50$ per article. This fee can be paid to the Materials Research Society through the Copyright Clearance Center, Inc., 27 Congress Street, Salem, MA 01970.

Membership in MRS is $\$ 75$ annually for regular members, $\$ 25$ for students and retired members. Dues include an allocation of $\$ 25$ ( $\$ 15$ for students and retirees) to a subscription to MRS Bulletin. Individual member subscriptions are for personal use only. Non-member subscription rates are $\$ 112$ for one calendar year (12 issues) within the U.S.A. and $\$ 165$ elsewhere. Single copies may be purchased for $\$ 16$ each. Send subscription orders to Subscription Department, Materials Research Society, 9800 McKnight Road, Pittsburgh, PA 15237.

MRS Bulletin is included in Current Contents/Physical, Chemical \& Earth Sciences'M Research Alert and the Materials Science Citation Index ${ }^{\mathrm{TM}}$. Back volumes of MRS Bulletin are available in $16 \mathrm{~mm}$ microfilm, $35 \mathrm{~mm}$ microfilm, or $105 \mathrm{~mm}$ microfiche through University Microfilms Inc., 300 North Zeeb Road, Ann Arbor, Michigan 48106 .

Materials Research Society • 9800 McKnight Road • Pittsburgh, PA 15237

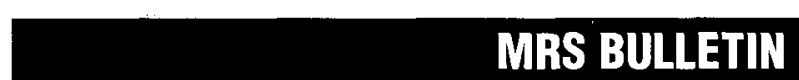

Publisher

Editor

E.L. Fleischer

Managing Editor

F.M. Wieloch

Copy Editors

J. Guenther, L.A. Krysinski,

S.W. Morelli, D.M. Varner

\section{Art Director}

C. Love

Design/Production

T. Aiello, S. Franklin

H.J. Miller

\section{Editorial Assistants}

M.M. Costello, J. Dininny

Advertising

M.E. Kaufold

Circulation

S.E. Krasa

Guest Editors

J. Li, J.W. Mayer and T.E. Seidel

Special Contributors

K.J. Anderson, A.E. West

Special Consultant

M. Goodway
Associate Editor-Europe

I.W. Boyd

University College London

Dept. of Electronic and

Electrical Engineering

Torrington Place

London WCI E7 JE, U.K

Tel. 71-387-7050 ext. 3956 or 7304

Book Review Editor

C.J. McHargue

University of Tennessee

Knoxville, Tennessee

MRS Office of Public Aflairs

555 13th Street NW, Suite 900 East

Washington, DC 20004

Tel. (202) 383-8809, Fax (202) 383-8877

CHAIRMAN-EOITORIAL BOARDS

E.N. Kaufmann • Argonne National Laboratory • Argonne, Illinois, USA

\section{INTERNATIONAL ADVISORY BOARD}

M. Balkanski

University of Pierre and Marie Curie

Paris, France

R.G. Elliman

Australian National University

Canberra, Australia

S. Hsu

Chung Shan Institute of Science and Technology

Taiwan, China

TECHNICAL EDITORIAL BOARD

\section{J.C. Bravman}

Stanford University

Stanford, California, USA

C.W. Draper

AT\&T Engineering Research Center

Princeton, New Jersey, USA

E. Fogarassy

Centre de Recherches Nucléaires

Strasbourg, France

L.C. Ianniello
U.S. Department of Energy
Washington, DC, USA

H-D. Li

National Science Foundation-China

Beijing, China

P. Rama Rao

Ministry of Science and

Technology

New Delhi, India

\section{F.Y. Fradin}

Argonne National Laboratory

Argonne, Illinois, USA

B.M. León

Universidad de Vigo

Vigo, Spain

G.L. Liedl

Purdue University

West Lafayette, Indiana, USA

\section{R. Roy}

Pennsylvania State University

University Park, Pennsylvania, USA

T. Sugano

Toyo University

Tokyo, Japan

D.L. Weaire

University of Dublin

Dublin, Ireland

\section{MRS BULLETIN PUBLICATIONS SUBCOMMITTEE}

\section{A.J. Hurd \\ J.M. Phillips}

Sandia National Laboratories

Albuquerque, New Mexico

M.R. Libera

Stevens Institute of Technology

Hoboken, New Jersey
AT\&T Bell Laboratories

Murray Hill, New Jersey

S.M. Prokes

Naval Research Laboratory

Washington, DC

\section{S. Namba}

Osaka University

Osaka, Japan

A.D. Romig Jr.

Sandia National Laboratories

Albuquerque, New Mexico, USA

J. Soares

Universidade de Lisboa

Lisboa, Portugal

K.C. Taylor

General Motors Research Laboratories Warren, Michigan, USA

\section{C.W. White}

Oak Ridge National Laboratory

Oak Ridge, Tennessee

\section{MRS EXECUTIVE COMMITTEE}

\section{President}

John C. Bravman

Stanford University

First Vice President and President-Elect

Julia M. Phillips

AT\&T Bell Laboratories

Second Vice President

Carl V. Thompson

Massachusetts Institute of Technology

\section{Secretary}

Carl C. Koch

North Carolina State University

Treasurer

A. Kay Hays

Sandia National Laboratories
Immediate Past President

S.T. Picraux

Sandia National Laboratories

Executive Director

Materials Research Society

John B. Ballance

\section{INTERNATIONAL UNION OF MATERIALS RESEARCH SOCIETIES}

President

Paul Siffert

Centre de Recherches Nucléaires.

France

Tel. (33) 882865 43; Fax (33) 88286293 IUMRS ADHERING BODIES

Australian Materials Research Society (A-MRS)

J.S. Williams

Chinese Materials Research Society (C-MRS)

Hengde Li

European Materials Research Society (E-MRS)

P.A. Glasow
Vice President

Masao Doyama

Nishi-Tokyo University, Japan

Tel. (81) 333390519 ;

Fax (81) 333100931

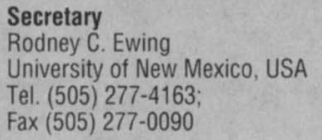

Treasurer

Li-Chung Lee

ITRI, Taiwan

Tel. (886) 35-820205

Fax (886) 35-820247
Immediate Past President

Secretary General

R.P.H. Chang

Northwestern University USA

Tel. (708) 491-3598; Fax (708) 491-4181

Materials Research Society (MRS)

John C. Bravman

Materials Research Society of India (MRS-I)

P. Rama Rao

Materials Research Society of Japan (MRS-J)

T. Masumoto 


\section{Introducing}
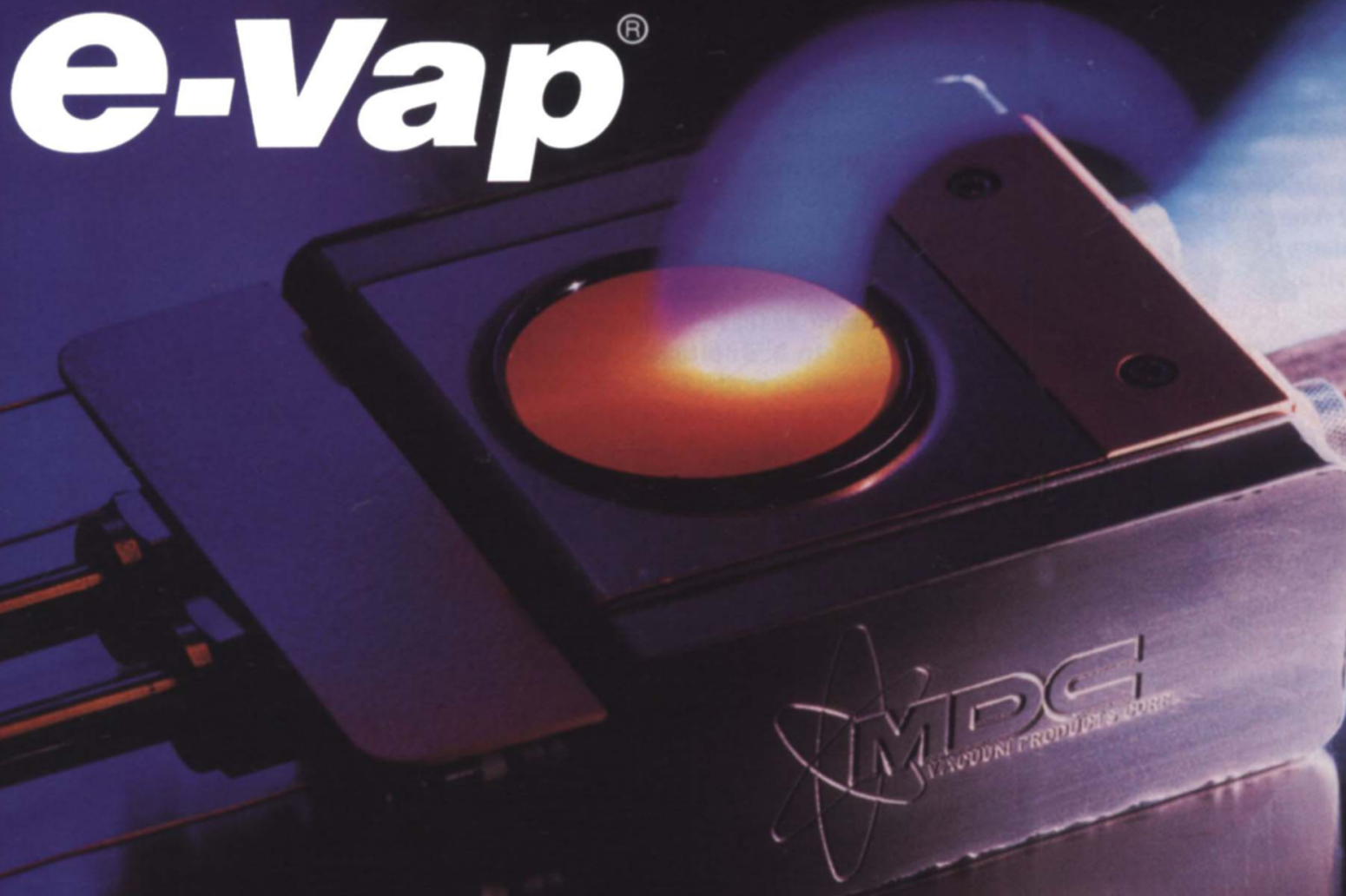

\section{Electron Beam Sources}

\section{for Advanced Thin Film Deposition}

From the co-inventor of SUPERSOURCE " comes e-Vap * the next major advance in applied electron beam technology.

e-Vap single and multiple crucible electron beam sources offer a consistent, uniform beam spot during the entire $x-y$ sweep, a flush top design to eliminate shadowing, shielded filaments, and heat-sinked emitter assemblies and much more. Replaceable $7 \mathrm{cc}$ to $40 \mathrm{cc}$ crucible modules are available for use in the same source body.

State of the art all-solid state electronics include compact e-Vap constant high voltage switching power supplies and programmable deposition rate controller monitors. Complete turn-key deposition systems are available.

MDC Vacuum Products Corp., 23842 Cabot Blvd. Hayward, CA 94545. Phone 510-887-6100 or 800-443-8817 toll free outside Calif. FAX 510-887-0626 